\title{
Effect of Article 11 of the Jordanian Electronic Crimes Law on Exercising Criticism Freedom for Journalists and Workers in the Digital Media
}

\author{
Sakher Ahmad Al-Khasawneh \\ Jordan Media Institute, Jordan - Amman
}

\begin{abstract}
This study aims to know the impact of the Jordanian Electronic Crimes Law No. 27 of 2015 on the freedom of the press and the freedom to exercise criticism in the digital media represented in websites and social networks. The study uses the descriptive method to survey the opinions of journalists, employees and activists in digital media field through a governed survey. The sample was randomly selected 150 individuals interested in studying their opinions and studying the effect of the law on their freedom of practicing criticism in many websites and social networks. The study found that $88 \%$ of journalists and workers in the digital media suffer from restrictions on their press freedoms through the censorship imposed by the editor and also through the penalties imposed by the Electronic Crimes Law regarding publishing crimes. In addition, an average of $75 \%$ of those who saw clear imbalances in the Electronic Crimes Law never corresponded to the freedom of the journalist in criticism. The results also showed that journalists and employees in the digital media are aware of the freedom of criticism and related supervisory roles. Are aware of their rights and duties in this regard with an average of $75 \%$ of the total knowledge, and $46 \%$ expressed their disagreement with the arrest of journalists in accordance with article 11 of the Electronic Crimes Law.
\end{abstract}

Keywords: Criticism of Electronic Crimes Law Article 11, Freedom of Information in Jordan.

DOI: $10.7176 / \mathrm{JLPG} / 85-07$

Publication date:May $31^{\text {st }} 2019$

\section{Introduction}

The Internet imposed a new media reality after its emergence in the late 20th century, giving people access to information at any time beyond the limits of distance, and spaces for exercising freedom of opinion and expression in the third world countries.

The Arab and Jordanian press played a major role in the use of internet and in creating news sites, giving the public's the opportunity to comment and contribute in the news industry, criticism of public practices, and unprecedented cases of exercising the right of criticism have been occurred. However, political and security conditions and misuse by agents represented in attacks on private life and in transferring false information. To give the government the justification to restrict the use of publishing on websites or social networks under the pretext of organizing.

\section{Study problem}

The problem of the study is to know the effect of Article 11 of the Electronic Crimes Law No. 27 of 2015, which states: "The freedom of press and the extent of the exercise of freedom of criticism through websites, especially that anyone who violates this article shall be punished by imprisonment from 3 months to 3 years and a week to not more than two months for a journalist, which constitutes a punishment precedent to the court's ruling and thus loss of the right of the journalist and the employee in the digital media to express his opinion and freedom of criticism for fear of imprisonment and detention of what he writes or published which means it did not give immunity to anyone, Restrictions on self-censorship practice to press their role in the criticism and censorship.

\section{The importance of studying}

The importance of this study lies in the fact that it is a part of legal and media studies that focuses on the knowledge of the journalists and employees of digital media attitudes regarding the applications of the Electronic Crimes Law No. 27 of 2015 and the extent to which the Jordanian legislator and the judiciary respect the freedom of criticism and the roles required by legislations. And to identify the main sources of imbalance in the application of this law from the perspective of protecting the freedom of media workers in the criticism and to know the extent of knowledge of journalists and employees in the digital media of the principle of this freedom and the associated oversight role and its impact on freedom of expression on the websites and thus documenting the actual application of this law.

\section{Objectives}

The purpose of this study is to know to what extent the press in general in Jordan and the digital media in particular 
have played their role in monitoring, accounting and freedom of criticism of the three authorities before and after the issuance of the Electronic Crimes Law in general.

1. Identify the extent websites' Jordanian journalists' knowledge of the of the principle of freedom of criticism and the associated supervisory role and to identify the sources of imbalance in the application of the Electronic Crimes Law from the perspective of protecting the journalist's right to freedom of criticism.

2. Identification of the extent to which Jordanian journalists know the limits of legal and moral responsibility available in censorship control and the impact of the Electronic Crimes Law Article 11 specifically on the freedom of expression on websites.

\section{Study Questions}

1. What is the extent of the press in general in Jordan and the electronic press in particular its monitoring role before and after the issuance of the Electronic Crimes Law?

2. How well do Jordanian journalists in websites and digital media professionals know about the principle of freedom of criticism and its associated supervisory role?

3. What are the sources of imbalances in the application of the Electronic Crimes Law from the perspective of protecting the journalist's freedom of criticism?

4. What are the trends of Jordanian journalists in news websites towards the restrictions imposed by the Electronic Crimes Law?

5. To what extent does the Electronic Crimes Law affect the freedom of expression of journalists on websites?

6. To what extent has the Electronic Crimes Law contributed to self-censorship of journalists' performance?

\section{Theoretical framework and previous studies}

(Al-Khaddam, Al-Rawashdah, 2012) Entitled "Media Practice between Professionalism, Custom and Law in Jordan"this study aimed at identifying the media practice in Jordan and highlighting the social influences ( customs ) and the professional influences on the media practice in Jordanian society, from the point of view of a sample of Jordanian media professionals working in media organizations. The researcher relied on the sample survey method to collect data. The random sample was formed from 245 media men and women. The study found that $17.7 \%$ of the media suffered from the prohibition of publication while $14.2 \%$ received the difficulty of obtaining information and $10 \%$ of them were summoned by the security services, $7.7 \%$ were threatened and temporary suspended while $5.4 \%$ And $5 \%$ of them were prosecuted. The study concluded that there is a clear impact of social knowledge on the media practice and the type of subjects that the media can deal with, such as those concerning personal, legal and sexual issues. And that there is an impact of the media professionalism represented by professional standards such as media codes of conduct and codes of conduct on media practice.

The study (Arrofoo', 2010), Entitled "Judicial Control of Decisions Restricting Freedom of Opinion and Expression, A Comparative Study between Jordan and Egypt", the study dealt with the issue of restrictions and obligations imposed on the press in the countries in question, and in the laws of publications and the extent of censorship, The study concluded that the Jordanian constitution has restricted the freedom of opinion and expression and provided for it in a flexible manner that allows for the inclusion of what it wants. This allowed the executive authority to put the restrictions it wants and to give officials in the executive authority a place to put restrictions on those rights, whether legislative or procedural. Which limit the scope of freedom of opinion and expression at times, or the practice of encouraging and intimidating journalists, The study also found the existence of restrictions imposed by the individual himself due to political, moral and social reasons, including the formation of caution over-cautious or fear sometimes,

Baloch, 2016, "Internet Rights and Legislation in Pakistan: Criticism of the Electronic Crimes Bill 2016", The study dealt with the Electronic Crimes Act of the Pakistan National Assembly on April 13, 2016, in which the Government of Pakistan was subjected to considerable opposition because of it from different segments of society. The study stated that various opposition parties had expressed reservations about the draft law during the deliberations of the Standing Committee on Information and Technology of the National Committee, while several organizations expressed serious concern about the draft law on the prevention of cybercrime 2016 on provisions violating freedoms, The study pointed out that the law aims to restrict the freedom of the Internet, including freedom of expression, access to information, the right to privacy, peaceful gatherings through the internet and association, because the law draft contains several sections open to ambiguous interpretation, leaving ample room for abuse and ill-treatment by authorities, as well as giving them full control over the common information on the internet and legitimate monitoring, where the preamble of the law indicates that the scope of the law is very broad for it addresses the investigation, the whole trial process, prosecution and most importantly talking about cooperation as it provides a mechanism for prosecuting the offenses set out in the law

Hwang, Laing, and Holder, 2016, "The Right of Freedom of Expression on the Internet as Applies to Social Media in Africa", which examined international legal and regional regimes governing freedom of expression and the use of social media in Africa as a whole and South Sahara in particular. The study also attempted to explore 
whether sub-Saharan African governments tried to suppress social media in the wake of the Arab Spring, and to know the legal means by which repression, from legislation and administrative methods, to suppressing the call to sites Means Social Media The study concluded that during the Arab Spring period, social media had a great influence especially in the Egyptian revolution. The study concluded that social media play a big role in mobilizing actors and civil society, which expose it to many challenges and must be protected. some policies must be changed to support the protection of freedom of expression through social media, which is particularly important in Africa where mobile technology is deployed.

(Joseph, 2012), study " social media, political change, and human rights". The study dealt with the role of social media in politics through the revolutions of the Arab Spring, and discussed how social media and the Internet can be tools for repression rather than liberation, Promoting hatred and propaganda rather than tolerance and democracy, and trying to study US policy on Internet freedom,

The study found that the Arab peoples were not ready for democratic transformation, and that the revolutions that youth had created through the social media could have led to excellent results in the direction of human rights and the raising of their standard of living. The study also showed that the means of social communication imposed a different media reality Through which the exchange of views and discussion and thus created an atmosphere of liberation.

Fish (2009),"Is the internet compatible with democracy? Legal restrictions on online speech in South Korea". The study aimed to analyze the internet censorship system in South Korea as a critical test case in the debate on the internet as a mean of democratic communication through restrictions on freedom of expression in South Korea, And how these restrictions formed the online censorship policy. The study concluded that, freedom of expression had not improved significantly under the democratic transition, but had declined until 2008, and that the problem was not only the failure of laws implement that protect freedom of expression but also the laws themselves, including those governing criminal defamation and information regulations online activities and the National Security law. South Korea needs more fundamental legal reform and strong defense of freedom of expression. Online censorship will only end if a government comes with a political will and power to put an end to such censorship as it weakens freedom of expression within countries.

\section{Comment on previous studies}

The findings of previous studies indicate that they are sort of old in view of the date of the Electronic Crimes Law in 2015. Some of them dealt with various aspects related to the legal restrictions on the media in several laws and how these laws play a role in limiting the freedom of the Jordanian media in all of its kinds. The Jordanian constitution restricts the freedom of opinion and expression and stipulated in flexible manner that allows inclusion of what he wishes to do. This allowed the executive authority in Jordan to thwart media freedom and analyzed the legal contents of freedom of opinion and expression such as the Press and Publications Law.

Therefore, this study will contribute in adding perspective of the journalists and their attitudes and evaluation of the legislative determinants imposed by the application of the law in the exercise of freedom of criticism and identify the most important sources of imbalance in the application of this law from the perspective of protecting the journalist's freedom of criticism and its impact in self-censorship.

\section{Theoretical framework}

\subsection{Freedom of information and related legislation in Jordan}

There is no doubt that the information revolution and the internet created a new space for freedom of expression, not only in Jordan but also globally. While the number of websites is an indicator of the freedom and democracy individuals enjoyed in a country, we find that the Arab world in general and Jordan in particular always aspires to control this space and determine its freedom.

No one can deny the role played by the electronic media in expanding the margin of freedom in the whole world. It has become a platform for citizens to freely express their opinions and become a fertile environment for critique and trying to improve policies and areas in which individuals actively participate in changing and forming public opinion towards fateful issues. In some cases, as in the Arab Spring revolutions, which were formed by invitations made by young people in social networking sites, which made electronic media a powerful weapon in some cases, governments sought to limit it by sometimes strict legislation and blocking internet services for individuals.

Although internet space and the Jordanian constitution in once pushed freedom forward and the political opposition rose and became more capable of expressing criticism of officials and the Jordanian regime, we cannot deny that this created a fertile environment for unprofessional irresponsible activities. The politicians have presented these incidents as a pretext to restrict electronic media, which sometimes made legislators enact laws guaranteeing individuals privacy rights without harmonizing these rights with the media's freedom to practice as a fourth power. freedom of expression is a right for every human being that able him or her express their opinion on any subject, at any time, place and by any means. It also contains other shapes of freedom such as freedom of 
press. It has also another facet: "The public's right to know, the right to seek and receive information, and sometimes freedom of expression conflicts with other important values and rights in a democratic society (Ali, 2015).

Voltaire, according to (Sahel 2014), was able to rise in the sense of freedom of thinking to say that there is no freedom of people without the freedom to express their thinking and this statement formed the rule of the declaration of human and citizen rights which stated in Article 11 "Free communication of ideas and opinions is the most valuable human rights every citizen can freely speak or write with the limitations given by the law". This text was later shed light in all of human rights instruments and freedom of expression, "holy" connection to the conscience that combines the responsible which is embodied more than three centuries in articles 18 and 19 of the Universal Declaration of Human Rights, which states: Everyone has freedom of thought, expression and religion. This right includes the freedom to change his religion and belief and to express it in education, practice, observance, in secretly or in public, and everyone has the right of free opinion and expression. This right includes the freedom to hold opinions without interference, to receive and impart information and ideas by any means without being bound by geographical boundaries.

The constitutions of the world adopted this text, including the Jordanian Constitution of 1952, which states in Article 15 that "The State shall guarantee freedom of opinion. Every Jordanian shall freely express his opinion in speech, writing, photography and other means of expression, publishing and broadcasting within the limits of the law. It is not permissible to suspend newspapers and the media, nor to revoke its license except by judicial order in accordance with the provisions of the law.

The Freedom House's annual report of 2017 points to a drop in world press freedom to its lowest level in 13 years in 2016 amid unprecedented threats to journalists and media in major democracies and new moves by authoritarian states to control the media, including beyond its borders, And that only $13 \%$ of the world's population enjoys free press - a media environment in which political news coverage is strong, journalists' safety is guaranteed, state media involvement is minimal, and the press is not subject to harsh law or economic pressures, while $45 \%$ of the population lives in countries Do not be Media environment is free. The 10 most-ranked countries and territories in the world are Azerbaijan, Crimea, Cuba, Equatorial Guinea, Eritrea, Iran, North Korea, Syria, Turkmenistan and Uzbekistan (Freedom Press, 2017).

In Jordan, the arrest of the writer Nahed Hattar, who has republished a post about ISIS on his personal Facebook page and was assassinated after receiving hundreds of death threats, raised questions about the government's ability and willingness to protect journalists and freedom of expression in general, In 2016 Jordanian journalists received orders to restrict what they wrote about the royal family and other sensitive subjects, which negatively affected the evaluation of freedoms in Jordan and took the bottom of the list of countries that enjoy freedom of expression (Freedom Press, 2017).

Freedom of information requires the right to access, transfer and exchange information from any source, the right to freely publish and share ideas and opinions, the right to publish newspapers and not to impose prior censorship on the media, but to the extent that freedom of information has a number of consequences, The media is subject to pre-censorship and limiting legislation that over-regulates, which in most cases restricts the freedom of the media and also restricts the right of individuals to exercise this freedom without interruption on the authority of the authorities (Sahel, 2014).

While Dr. Hosni Nasr believes that one of the most important issues surrounding the electronic press - as in the traditional press - the issue of freedom and related legislation, laws, practices and restrictions. Since the beginning of the Internet, the issue has entered the public sphere of interest among the Internet users and governments (Nasr, 2014).

Digital media, mainly the web, are alternative ways to support freedom when the government restricts traditional media (journalism, radio and television) in any country, and only dictatorial regimes can impose restrictions on media freedoms and freedom of the press. Find ways to curb freedom of information. Although it is believed that freedom of the press in democratic countries is guaranteed, evidence shows that restrictions can be similar to those in authoritarian regimes or themselves. Therefore, blogs and social media have become a substitute for mainstream media (Praeli, 2010).

\subsection{Legislative frameworks in Jordan}

The successive Jordanian governments have resorted to legislation to influence the media as the fastest tool to narrow it and to tighten punitive legislation as a means to achieve that goal. It considers it the fastest way to control and develop the media and to consider the new digital media as a matter of necessity (Qutishat and Hussni, 2015).

Mohammed Al-Momani said that the Jordanian government's experience to deal with the Jordanian media, which came at the political level and at the level of the vision, appreciates the role of electronic media and understands that it is important that cannot be bypassed or controlled as some officials in other places do because it realizes that it is a The media and the development of the press and recognizes the need to deal positively with this phenomenon, which carries a lot of good for communities, where the citizen is familiar with a lot of 
information, which contributes to raising the level of public knowledge and reflected on the degree of advancement of peoples and communities, and the result of massive expansion in the sites So it was necessary to take legal constitutional steps to regulate this matter and not to limit the freedom of the press. There is no freedom without responsibility and the synthesis of freedom and responsibility does not hinder the press. It is an ethical and moral duty for every journalist in every word he writes or prints. In the end, he is the one who makes public opinion (Momani, 2014).

Legislation governing digital media has passed through three stages:

In order to explain the stages that the websites have undergone in terms of legal organization, and the comprehensive coverage of the law and the law, we will divide it into three stages:

9.2.1 stage I (2006-2011):

As the first news website in Jordan was established in July 2006, the offenses involving defamation and manslaughter were considered by the Magistrate's Courts as cases of defamation and manslaughter subject to the general rules of the Jordanian Penal Code until the decision of the Court of Cassation in Criminal Case No. (2009/1729) 10/1/2010, which considered that the websites fall within the definition of publications in general and are subject to the law of publications and publishing, and based on this decision if the publication on the Web sites, including what is defamatory or sham, the competent court is the Court of First Instance, Article (46) Whoever violates the provisions of paragraph (d) of Article (38) shall be punished by a fine not less than five hundred dinars and not more than one thousand dinars.

According to the previous decision, the definition of the publication in the amended Press and Publications Law No. 17 of 2011 was amended to read: "Any publication in which the meanings, words or ideas are published in any way, including electronic, digital or technical means.

This was regarded as a positive phase of the Press and Publications Law in article 42, which grants journalists under the jurisdiction a number of advantages, including but not limited to the detention of journalists, and the penalties stipulated in the law are the same as fines in article 46 thereof.

9.2.2 stage II (2012-2015):

And the redefinition of the electronic publication "A web site has a specific electronic information network that provides publishing services, including news, reports, investigations, articles and comments. The registration is chosen in a special register established by the Authority under instructions issued by the minister for this purpose ". The amendment shall be subject to Article 49 if the electronic publication activity is to publish news, inquiries, articles and comments related to the internal or external affairs of the Kingdom. This publication shall be bound by registration and authorization by the director. The owner of the electronic publication shall comply with the provisions of this law within a period not exceeding ninety days from the date of notification of such decision by the director.

The most serious legislative development at this stage is the subject of commenting on the published news in the provisions of the Press and Publications Law. Article 49 / C "Comments published in the electronic publication shall be considered as a press item for the purposes of the responsibility of the electronic publication and its owner and its editor in solidarity and solidarity.

The e-publication law requires, under paragraph e, "to maintain a record of published comments, provided that this record contains all information relating to the authors of the comments and the article of suspension for at least six months."

The amendment has resulted in the reluctance of citizens to comment or block websites to comment on published material. To circumvent this prohibition and the lack of coverage of the social media sites to enforce the Press and Publications Law, the news websites re-publish their news on social networking pages and allow citizens to re-publish and comment Through social networking pages.

9.2.3 stage III (beyond 2015):

The Electronic Crimes Law No. 27 of 2015 and its entry into force on June 1 of the same year may have been promulgated. The law contains the text of Article 11, which states: "Anyone who intentionally sends, resends or publishes data or information via the Internet or the website Or any information system involving defamation, defamation or defamation of any person for a term of not less than three months and a fine not less than (100) hundred dinars and not more than (2000) thousand dinars.

This text, although external, is not directly linked to online publishing, but the truth is otherwise. The legal and judicial application of article 11 has come to cover all publishing and republishing on the Internet.

The law did not show the seriousness of the law in particular, and the media and media in general, except when the Attorney General of Amman decided to arrest a journalist on a press article published on the website, stating that the Electronic Crimes Law is a special law and applies to electronic publishing without the provisions of the Press and Publications Law, His power to arrest does not contradict what is stated in the Publications Law.

In his decision to arrest, contrary to the provisions of the Press and Publications Law, the Attorney-General did not rule out the suspension of journalists to Decree No. 8 of 2015 on the interpretation of laws. Article (11) of the Electronic Crimes Law through websites and social networking sites is subject to this article and Article (114) 
of the Code of Criminal Procedure and not Articles 42 and 45 of the Press and Publications Law.

\subsection{Freedom of criticism}

The definition of criticism came according to a general Arabic dictionary, in the sense of distinguishing the dirham by looking at it for its badness, and also criticizing the speech to show its flaw, and also in the sense of the discussion, critic criticizes any criticism, as it is said.

His definition came as a comment, and it was directed at the acting, and he did not know what to do with the meaning of the verse (Ramadan, 1986).

It is noted that most laws, whether in the Latin system or the Anglo-American system, do not specify texts specific to the boundaries of journalistic criticism and do not provide for the reason for openness on the face of independence, which called for the judiciary to activate the constitutional texts Which established the Constitutional Council of France as a basis for the legitimacy of the right of criticism (Sorour, 1997).

therefore, there is no difference in legislation on the basis of the right of criticism, but the fundamental difference is due to the use of the judiciary in various countries with the constitutional texts, and the US judiciary is the most prominent and most effective in this regard, given the broad powers granted to the Federal Supreme Court in the interpretation and application Constitutional Texts (Ramadan, 1999).

The jurisprudence in Jordan has determined that the exercise of the right of criticism is the aim of the press and its responsibility to put the public and citizen in the form of mistakes made by the administration in matters directly prejudicial to his life. Such articles constitute the actual concept of freedom of the press and media to obtain information from any source and transfer And the right to disseminate these ideas and opinions and exchange without restrictions and therefore the goal of the articles is the public interest and not the mocking and insulting and contempt of the people of public administration and therefore this constitutes the use of the right to publish news and such articles is considered permissible criticism is to show the In any order or action, without prejudice to the person of the owner of it or work in order to slander or disparage the dignity and it reportedly does not constitute defamatory articles or invective, but legally permissible work given the status of it was issued. (Decision of the Court of Appeal of Amman no. 13805/2009).

\section{Study Approach}

This study is descriptive. This method relies on a structured questionnaire as a tool for gathering information in this study. It raises questions from previous studies on a number of employees in the Jordanian digital media sites, including news websites, production companies and technical distribution active in the field of digital media and Social communication interested in criticism of the work of the government and comment on public figures and legal, and then analyze those data.

\section{Population and sample}

The study community consists of journalists working on the websites of traditional media and journalists working on the news websites, which number 191 sites and workers in the production companies and technical distribution active in the field of digital media and the number of two companies according to the media and the study community included a number of activists in social networking sites Who are interested in critiquing the work of the government and commenting on public figures.

The study sample consisted of 150 individuals, which were divided into categories. The percentage of each category was determined according to the representation of this group in the original community. These categories are as follows:

1. Journalists working on traditional media websites represented $30 \%$ of the sample size.

2. Journalists working on news websites represented $55.4 \%$ of the sample.

3. Workers in production and technical distribution companies active in the field of digital media represented $7.3 \%$ of the sample size.

4. Activists on social networking sites and bloggers accounted for $7.3 \%$ of sample size.

A total of 160 items were distributed, of which 150 were returned for analysis and none were neglected.

\section{Characterization of the study sample}

The sample consisted of 150 persons. The following table shows the number of males and females participating with the percentage of the total sample: 
Table 1. Number and percentage of males and females of the total sample size

\begin{tabular}{|c|c|c|c|}
\hline & & No. & Percentage $\%$ \\
\hline \multirow{2}{*}{ Gender } & males & 94 & 62.7 \\
\hline & females & 56 & 37.3 \\
\hline \multicolumn{2}{|c|}{ Total } & 150 & 100 \\
\hline \multirow{11}{*}{ work nature } & Press Reporter & 35 & 23.3 \\
\hline & News editor & 32 & 21.3 \\
\hline & Editor secretary & 16 & 10.7 \\
\hline & Editing Manager & 16 & 10.7 \\
\hline & Chief of editing & 3 & 2.0 \\
\hline & Photographer & 3 & 2.0 \\
\hline & Article writer & 6 & 4.0 \\
\hline & Journalist & 20 & 13.3 \\
\hline & Digital Film Producer & 5 & 3.3 \\
\hline & Digital screenplay writer & 3 & 2.0 \\
\hline & Blogger & 11 & 7.3 \\
\hline \multicolumn{2}{|c|}{ Total } & 150 & 100 \\
\hline \multirow{2}{*}{ Comment on the news } & Yes & 81 & 54.0 \\
\hline & No & 69 & 46.0 \\
\hline \multirow{2}{*}{ Electronic Publishing } & Yes & 124 & 82.7 \\
\hline & No & 26 & 17.3 \\
\hline \multirow{2}{*}{$\begin{array}{c}\text { Publish to your personal } \\
\text { account via social media sites }\end{array}$} & Yes & 110 & 73.3 \\
\hline & No & 40 & 26.7 \\
\hline \multicolumn{2}{|c|}{ Total } & 150 & 100 \\
\hline
\end{tabular}

\section{Study tool}

The questionnaire was the study tool and consisted of 56 different questions. These questions were related to each other to achieve the objectives of the study.

\section{The limits of the study}

- Spatial Limit: All websites and specialized production companies in the field of digital media operating in Jordan.

- The human limit: The workers in these sites and the production companies whose work nature requires critique and commentary on the news.

- Time limit: 8-10/2018.

\section{Methods of data collection}

- Primary Sources: The study took the questionnaire as a primary source and data collection tool, consisting of six main axes.

- Secondary Sources: The study used sources of secondary materials, which include books, previous studies and research papers related to the subject of the study.

This study adopted several methods to classify the responses of the sample members to determine their attitudes and opinions towards the law and the extent to which they exercised freedom of criticism in the light of Article 11, where he used the Likert triangular and pentagonal scale to answer the study axes.

\section{Validity of the questionnaire tool}

The validity of the content was verified by presenting it to a number of arbitrators from the media professors at the Petra University, the Arab Open University and the Jordan Media Institute to ascertain the extent of their coverage of all aspects of the subject, the clarity of their terms, the integrity of their language formulation, and their relevance to the axis to which they belong. Where the teachers noted a number of amendments to some paragraphs and the addition of other paragraphs have been taking notes.

\section{Standardization of standards and criterion for judging paragraphs}

The standards of the practice of the press for the monitoring role, the measure of trends and the measure of the effect of the law on the freedom of expression of journalists and the measure of the extent of the law's contribution to self-censorship were graded (three, three, (One degree), and the study adopted the criterion of the following provision on the paragraphs:

(Highest rank - lowest grade) / number of categories: $(3-1) / 3=0.66$ 
- $\quad$ From 1.66 to 1.66 , and from 1.67 to 2.33, and from 2.34 to 3. High.

- The percentage of paragraphs was extracted by adopting the following criteria:(Paragraph / top grade) $* \%$ The standard from $33 \%$ to $55 \%$ low, from $56 \%$ to $77 \%$ average and from $78 \%$ to $100 \%$ high.

The scale of the sources of the imbalance and the scale of the journalists' knowledge of freedom of criticism were determined by the five-point Likert scale (strongly agree, agree, neutral, disagree, strongly disagree), with a strongly agree score (5), Agree (4), neutral (3) disagree (2), strongly disagree (1) . The course adopted the following judgment on the paragraphs:

(Highest level - lowest grade) / number of categories: (5-1)/ $3=1.33$

From 1 to 2.33 (low), from 2.34 to 3.66 (medium), and from 2.67 to 5 (high).

The percentage of paragraphs was extracted by adopting the following criteria: (Paragraph / top grade) $* \%$ The standard from $20 \%$ to $46.6 \%$ is low, from $46.7 \%$ to $73.2 \%$ average, and from $73.3 \%$ to $100 \%$ high.

\section{Results}

18.1 Supervisory role exercised by the press and digital media before and after the issuance of the Electronic Crimes Law

Table 2. Arithmetical mean, standard deviations, percentages, and extent of press practice in general in Jordan and digital media in particular their monitoring role before and after the Electronic Crimes Law was issued in descending order

\begin{tabular}{|c|c|c|c|c|c|c|}
\hline Rank & No. & item & Mean & $\begin{array}{l}\text { St. } \\
\text { deviation }\end{array}$ & percentage & $\begin{array}{l}\text { Practical } \\
\text { rang }\end{array}$ \\
\hline 1 & 8 & $\begin{array}{l}\text { That the material posted on the websites that } \\
\text { involve defamation and mug is governed by } \\
\text { the Electronic Crimes Act }\end{array}$ & 2.70 & .5780 & $90 \%$ & high \\
\hline 2 & 10 & $\begin{array}{l}\text { Journalism is subject to the control of the } \\
\text { editor, editor, or director. }\end{array}$ & 2.65 & 0.593 & $88 \%$ & high \\
\hline 3 & 6 & $\begin{array}{l}\text { Laws restrict digital media by imposing penal } \\
\text { sanctions (imprisonment) }\end{array}$ & 2.56 & 0.586 & $85 \%$ & high \\
\hline 4 & 1 & $\begin{array}{l}\text { Do you have knowledge of the laws that } \\
\text { regulate the work of the press in Jordan or } \\
\text { contain in its texts what about the press? }\end{array}$ & 2.55 & 0.599 & $85 \%$ & high \\
\hline 5 & 4 & $\begin{array}{l}\text { The ceiling of journalistic freedoms on } \\
\text { websites is higher than the written press. }\end{array}$ & 2.45 & .674 & $82 \%$ & high \\
\hline 6 & 7 & $\begin{array}{l}\text { The multiplicity of legislation governing } \\
\text { publishing on websites limits the exercise of } \\
\text { their work. }\end{array}$ & 2.35 & .699 & $78 \%$ & high \\
\hline 7 & 5 & $\begin{array}{l}\text { Digital media is subject to the same laws } \\
\text { governing publications and printed material. }\end{array}$ & 2.26 & .750 & $75 \%$ & Mid. \\
\hline 8 & 2 & $\begin{array}{l}\text { Jordanian laws restrict media freedom in your } \\
\text { personal opinion? }\end{array}$ & 2.23 & .609 & $74 \%$ & Mid. \\
\hline 9 & 9 & $\begin{array}{l}\text { I support tougher penalties for publishing } \\
\text { crimes on websites. }\end{array}$ & 2.23 & .828 & $74 \%$ & Mid. \\
\hline 10 & 3 & $\begin{array}{l}\text { Jordanian laws guarantee freedom of } \\
\text { information in your personal opinion? }\end{array}$ & 1.87 & .622 & $62 \%$ & Mid. \\
\hline \multicolumn{3}{|c|}{ Total average of practice. } & 2.39 & .269 & $80 \%$ & high \\
\hline
\end{tabular}

Table (2) shows the overall extent of the press practice in Jordan and the digital media in particular. Their monitoring role before and after the crime law came to mean the general average of the practice by an average of (2.39) and a percentage (80\%). The percentages of the questions ranged from 1.87 to 2.70 , with a percentage ranging between $62 \%$ and $90 \%$. This was due to the high and average level of practice. It was stated that the material published on the websites, $(90 \%)$ and with a high level of practice, followed by paragraphs (Journalism shall be subject to the control of the Editor-in-Chief, Editor-in-Chief or Director), and the digital media shall be subject to penal sanctions (2.56) and by percentage ( $88 \%$ ) and by the average practice, while (A. Jordanian laws to ensure freedom of the media personal opinion) the last level of practice and the extent of an arithmetic mean (1.87) by a percentage (62\%) and the extent of the exercise of the average. 
18.2 Sources of imbalances in the application of the Electronic Crimes Law from the point of view of protecting the journalist's right to criticism

Table3. The arithmetic mean, standard deviations, percentages and degree of sources of imbalances in the application of the Electronic Crimes Law from the point of view of protecting the right of the journalist to cash in descending order

\begin{tabular}{|c|c|c|c|c|c|c|}
\hline rank & No. & item & Mean & $\begin{array}{c}\text { St. } \\
\text { deviation }\end{array}$ & percentage & Degree \\
\hline 1 & 6 & $\begin{array}{l}\text { The Electronic Crimes Law does not distinguish } \\
\text { between publication on the website and social } \\
\text { networking sites in terms of responsibility. }\end{array}$ & 3.95 & 1.022 & $79 \%$ & High \\
\hline 2 & 4 & $\begin{array}{l}\text { The Electronic Crimes Act does not distinguish } \\
\text { between a journalist and a non-journalist. }\end{array}$ & 3.94 & 1.062 & $79 \%$ & High \\
\hline 3 & 5 & $\begin{array}{l}\text { The Electronic Crimes Law expands the concept } \\
\text { of slander and slander and includes slander and } \\
\text { slander on natural and legal persons. }\end{array}$ & 3.94 & .998 & $79 \%$ & High \\
\hline 4 & 9 & $\begin{array}{l}\text { Legal liability for electronic publishing includes } \\
\text { the original author, commentator, editor, and } \\
\text { publisher. }\end{array}$ & 3.82 & 1.044 & $76 \%$ & High \\
\hline 5 & 7 & $\begin{array}{l}\text { The material published on the websites shall be } \\
\text { treated either by publishing, republishing, } \\
\text { transmitting or reprinting a substance that } \\
\text { involves the same original article. }\end{array}$ & 3.78 & 1.040 & $76 \%$ & High \\
\hline 6 & 1 & $\begin{array}{l}\text { Electronic Crimes Act allows the Prosecutor to } \\
\text { arrest. }\end{array}$ & 3.76 & 1.131 & $75 \%$ & High \\
\hline 7 & 3 & $\begin{array}{l}\text { Law in that the latter does not permit the arrest or } \\
\text { imprisonment of journalists. }\end{array}$ & 3.66 & 1.173 & $73 \%$ & Mid. \\
\hline 8 & 2 & $\begin{array}{l}\text { The penalty of publication contrary to Article } 11 \\
\text { of the Electronic Crimes Law is imprisonment } \\
\text { from } 3 \text { months to } 3 \text { years. }\end{array}$ & 3.54 & 1.135 & $71 \%$ & Mid. \\
\hline 9 & 8 & $\begin{array}{l}\text { In investigating electronic publishing cases, the } \\
\text { prosecutor does not have a decision that the article } \\
\text { involves freedom of criticism. }\end{array}$ & 3.36 & 1.076 & $67 \%$ & Mid \\
\hline \multicolumn{3}{|c|}{ Total average of sources of imbalance } & 3.75 & .719 & $75 \%$ & High \\
\hline
\end{tabular}

Table (3) shows that the degree of sources of imbalances in the application of the Electronic Crimes Law from the point of view of protection of the journalist's right to cash came to the average of the degree of imbalances at an average of (3.75) and 75\% (high percentage), while the arithmetic averages of the paragraphs related to sources of imbalances between (3.36 and 3.95), and percentage ranged between $67 \%$ and $79 \%$. It came at a high and medium level. The paragraph (Electronic Crimes Law expands the concept of slander and slander and includes slander and slander on natural and legal persons) With a mean (3.95) percentage point (79\% and high, followed by The Electronic Crimes Law does not discriminate between journalists and non-journalists within the scope of liability. The Electronic Crimes Law does not discriminate between publication on the website and the social networking sites in terms of liability (3.94\%) and 79\% (In the investigation of electronic publishing cases, the public prosecutor does not have a report that the material involves freedom of criticism) is the last rank of the sources of imbalances and the average (3.36) percentage (67\%) and to a medium degree. 
18.3 Knowledge of Jordanian journalists in the websites of the principle of freedom of criticism

Table 4. Computational averages, standard deviations, percentages, and extent of Jordanian journalists' knowledge of the websites of the principle of freedom of criticism and the associated supervisory roles in descending order

\begin{tabular}{|c|c|c|c|c|c|c|}
\hline rank & No. & item & Mean & $\begin{array}{c}\text { St. } \\
\text { deviation }\end{array}$ & percentage & Degree \\
\hline 1 & 4 & Caricature is a method of criticism. & 4.28 & .834 & $86 \%$ & high \\
\hline 2 & 5 & The overall average range of knowledge. & 4.28 & .817 & $86 \%$ & high \\
\hline 3 & 1 & $\begin{array}{l}\text { The right of criticism is "to express an opinion on } \\
\text { any matter or business without prejudice to the } \\
\text { person in charge of the order or work that is not } \\
\text { prejudicial to his or her honor." }\end{array}$ & 4.23 & .892 & $85 \%$ & high \\
\hline 4 & 16 & $\begin{array}{l}\text { The electronic press can exercise the freedom of } \\
\text { criticism. }\end{array}$ & 4.18 & .892 & $84 \%$ & high \\
\hline 5 & 12 & $\begin{array}{l}\text { Freedom of cash requires access to information } \\
\text { from its sources. }\end{array}$ & 4.11 & 1.014 & $82 \%$ & high \\
\hline 6 & 8 & $\begin{array}{l}\text { Criticism is directed at the public figure and as it } \\
\text { did. }\end{array}$ & 4.09 & .928 & $82 \%$ & high \\
\hline 7 & 11 & $\begin{array}{l}\text { Freedom of criticism represents the role of the } \\
\text { press in controlling government actions. }\end{array}$ & 4.08 & .990 & $82 \%$ & high \\
\hline 8 & 9 & The criticism goes to topics of public interest. & 4.03 & .925 & $81 \%$ & high \\
\hline 9 & 3 & $\begin{array}{l}\text { The journalist can comment on the news and use } \\
\text { harsh criticism without compromising the } \\
\text { person's status, honor or prestige. }\end{array}$ & 3.99 & .979 & $80 \%$ & high \\
\hline 10 & 15 & $\begin{array}{l}\text { The lack of conflicting interests of the journalist } \\
\text { with the public figure legitimizes the criticism } \\
\text { directed at the actions of public figures (good } \\
\text { faith). }\end{array}$ & 3.99 & .958 & $80 \%$ & high \\
\hline 11 & 17 & $\begin{array}{l}\text { Editorial rules in print journalism differ from rules } \\
\text { in digital media. }\end{array}$ & 3.61 & 1.132 & $72 \%$ & Mid. \\
\hline 12 & 14 & $\begin{array}{l}\text { The publication of comments on the news, which } \\
\text { includes criticism of public figures, including } \\
\text { their personal lives and images, is a violation of } \\
\text { the principle of freedom of criticism }\end{array}$ & 3.57 & 1.293 & $71 \%$ & Mid \\
\hline 13 & 13 & $\begin{array}{l}\text { The publication of comments on the news, which } \\
\text { includes criticism of public figures without } \\
\text { mentioning their source, is a violation of the } \\
\text { principle of balance in the work of the press. }\end{array}$ & 3.52 & 1.149 & $70 \%$ & Mid \\
\hline 14 & 10 & $\begin{array}{l}\text { A journalist can freely use words, drawings or } \\
\text { pictures commensurate with the gravity of the act, } \\
\text { however harsh it may be. }\end{array}$ & 3.33 & 1.171 & $67 \%$ & Mid \\
\hline 15 & 6 & $\begin{array}{l}\text { Publishing public photos in public places of } \\
\text { public figures is a method of freedom of criticism. }\end{array}$ & 3.07 & 1.380 & $61 \%$ & Mid \\
\hline 16 & 7 & $\begin{array}{l}\text { Composite images of public figures are free to } \\
\text { criticize. }\end{array}$ & 2.71 & 1.340 & $54 \%$ & Mid \\
\hline 17 & 22 & $\begin{array}{l}\text { The right of criticism is an accusation and a } \\
\text { permissible dish. }\end{array}$ & 2.40 & 1.307 & $48 \%$ & Mid \\
\hline \multicolumn{3}{|c|}{ Total average of Knowledge } & 3.73 & .515 & $75 \%$ & high \\
\hline
\end{tabular}

Table (4) shows that the extent of knowledge of Jordanian journalists in the websites of the principle of freedom of criticism and its associated supervisory role came to the average of the principle of freedom of cash at an average of (3.73) and a percentage (75\%). While the arithmetic averages for the knowledge-related paragraphs ranged between 3.40 and 4.28 and by percentage of the percentages $(48 \%$ and $86 \%)$. The differences were (Cartoons are criticisms, and the sarcastic is one of the methods of guidance $(86 \%)$ and with a high level of knowledge, followed by paragraph (the right of cash is "to express opinion in a matter or business without prejudice to the person in charge of the order or work, ie no (A) is affected by his or her honor ") with an average of (4.23) percentage (85\%) and with a high level of knowledge, while the paragraph (the right of criticism is an accusation) $\mathrm{H}$ are permissible), the last level of knowledge and the extent of an arithmetic mean (2.40) as a percentage (48\%) and the extent of medium knowledge. 
18.4 The Jordanian journalists' attitudes towards the electronic restrictions on cybercrime

Table 5. The statistical averages, standard deviations, percentages, and degree of Jordanian journalists' attitudes towards electronic restrictions are ranked in descending order

\begin{tabular}{|c|c|l|c|c|c|c|}
\hline rank & No. & \multicolumn{1}{|c|}{ item } & Mean & $\begin{array}{c}\text { St. } \\
\text { deviation }\end{array}$ & percentage & Degree \\
\hline 1 & 1 & Overall mean of degree of direction. & 2.24 & .773 & $75 \%$ & mid \\
\hline 2 & 2 & $\begin{array}{l}\text { Do you agree to restrictions on electronic } \\
\text { journalism? }\end{array}$ & 2.08 & .754 & $69 \%$ & mid \\
\hline 3 & 5 & $\begin{array}{l}\text { Do you agree that the editor-in-chief and the } \\
\text { journalist are equal in punishment? }\end{array}$ & 1.97 & .814 & $66 \%$ & mid \\
\hline 4 & 4 & $\begin{array}{l}\text { Do you agree to the equality of electronic } \\
\text { publishing with social networking sites? }\end{array}$ & 1.88 & .784 & $63 \%$ & mid \\
\hline 5 & 3 & $\begin{array}{l}\text { Do you agree to the publisher's equality with the } \\
\text { publisher in the punishment? }\end{array}$ & 1.81 & .822 & $60 \%$ & mid \\
\hline $\begin{array}{l}\text { Do you agree to the arrest of journalists in } \\
\text { accordance with Article 11 of the Electronic } \\
\text { Crimes Law? }\end{array}$ & 1.69 & .775 & $56 \%$ & mid \\
\hline 7 & 6 & $\begin{array}{l}\text { Do you accept the equality of the journalist with } \\
\text { non-journalists when publishing and commenting } \\
\text { on websites and social networking sites? }\end{array}$ & 1.63 & .733 & $54 \%$ & low \\
\hline \multicolumn{2}{|c|}{ Average } \\
\hline
\end{tabular}

Table (5) shows that the degree of Jordanian journalists' attitudes towards the electronic crime websites to the restrictions imposed by the Electronic Crimes Law is (1.90) for the general average of the degree of trends and percentage $(63 \%)$ and to a medium degree. While the arithmetic average of the questions about the trends towards the restrictions ranged between 1.63 and 2.24 and $54 \%$ and $75 \%$ respectively. (2.24) percentage (75\%) and medium level, followed by the paragraph (Do you agree to restrictions on the electronic press?) With an average of (2.08) percentage $(69 \%)$ and, to a medium extent, When did you agree to the arrest of journalists in accordance with Article 11 of the Electronic Crimes Law? (1.63) percentage points (54\%) and with a low trend.

18.5 The impact of the Electronic Crimes Law on the freedom of expression of journalists on the websites

Table 6. Arithmetical mean, standard deviation, percentages and the extent to which the Electronic Crimes Law affects the freedom of expression of journalists on websites in descending order

\begin{tabular}{|c|c|l|c|c|c|c|}
\hline rank & No. & \multicolumn{1}{|c|}{ item } & $\begin{array}{c}\text { Arith. } \\
\text { mean }\end{array}$ & $\begin{array}{c}\text { Stn. } \\
\text { deviation }\end{array}$ & percentage & $\begin{array}{c}\text { Impact } \\
\text { degree }\end{array}$ \\
\hline 1 & 3 & $\begin{array}{l}\text { Have you become more cautious in using } \\
\text { your freedom to criticize public figures? }\end{array}$ & 2.35 & .639 & $78 \%$ & high \\
\hline 2 & 5 & $\begin{array}{l}\text { Does the Cybercrime Law restrict freedom of } \\
\text { expression on websites and social networking } \\
\text { sites? }\end{array}$ & 2.35 & .650 & $78 \%$ & high \\
\hline 3 & 4 & $\begin{array}{l}\text { Has the editorial style changed and } \\
\text { commented on after the e-Crime Act? }\end{array}$ & 2.22 & .678 & $74 \%$ & mid \\
\hline 5 & 1 & $\begin{array}{l}\text { Have you become less able to exercise your } \\
\text { right to express your opinion after the } \\
\text { Electronic Crimes Law? }\end{array}$ & 2.21 & .724 & $74 \%$ & mid \\
\hline \multicolumn{2}{|l|}{ Average you stopped commenting on the news } \\
after the Electronic Crimes Law?
\end{tabular}

Table (6) shows that the extent of the impact of the Electronic Crimes Law on the freedom of expression of journalists on the websites was as to the effect of the law on the freedom of expression of journalists at an average of (2.23) percent (74\%) and the average effect.

While the arithmetic average of the questions regarding the extent of the impact of the Electronic Crimes Law on the freedom of expression of journalists was between 1.99 and 2.35 , with a percentage ranging from $66 \%$ to $78 \%$, with a high and average effect. Two questions were asked: Are you more cautious in using your freedom to criticize the actions of public figures? Is the Electronic Crimes Law restricting the freedom of expression on websites and social networking sites?) In the first rank of the impact of the Electronic Crimes Law on the freedom of expression of journalists and an average of 2.35 percentage points (78\% With a high impact, followed by the question (do you agree with the equality of punishment between the publisher and the republishre?) With an average of (2.22) percentage points (74\%) and with a medium effect, while the question (did you stop commenting 
on the news after the Electronic Crimes Law?) Came at the last level with the effect of the freedom of expression of journalists (1.99) percentage (66\%) and the average effect.

18.6 Electronic Crimes Law and its contribution to self-censorship of journalists' performance

Table 7. Arithmetic mean, standard deviation, percentages, and the extent to which the Electronic Crimes Law contributes to self-censorship of the performance of journalists in descending order

\begin{tabular}{|c|c|c|c|c|c|c|}
\hline rank & No. & item & $\begin{array}{l}\text { Arith. } \\
\text { mean }\end{array}$ & $\begin{array}{l}\text { Stn. } \\
\text { Devi. }\end{array}$ & Perc. & $\begin{array}{l}\text { Cont. } \\
\text { degree }\end{array}$ \\
\hline 1 & 6 & $\begin{array}{l}\text { Do you think that security prosecutions have limited the } \\
\text { exercise of work (freedom of criticism). }\end{array}$ & 2.27 & .678 & $76 \%$ & mid \\
\hline 2 & 4 & $\begin{array}{l}\text { Do you think that the punishment in the Cybercrime Act } \\
\text { has limited the exercise of work (freedom of criticism)?. }\end{array}$ & 2.24 & .686 & $75 \%$ & mid \\
\hline 3 & 5 & $\begin{array}{l}\text { Do you think that pre-trial detention in the Cybercrime Act } \\
\text { has limited the exercise of work (freedom of criticism)?. }\end{array}$ & 2.21 & .664 & $74 \%$ & mid \\
\hline 4 & 3 & Have you increased your self-control when doing work? & 2.18 & .719 & $73 \%$ & mid \\
\hline 5 & 7 & $\begin{array}{l}\text { Do you think that it is the authority of the director or the } \\
\text { editor-in-chief and the joint responsibility for publishing } \\
\text { that limit the exercise of work (freedom of criticism)? }\end{array}$ & 2.10 & .634 & $70 \%$ & mid \\
\hline 6 & 8 & $\begin{array}{l}\text { Do you think that dismissal penalties are the ones that limit } \\
\text { the exercise of work (freedom of criticism)? }\end{array}$ & 2.01 & .717 & $67 \%$ & mid \\
\hline 7 & 1 & $\begin{array}{l}\text { Has an issue ever been filed against you for an electronic } \\
\text { publication? }\end{array}$ & 1.32 & .682 & $44 \%$ & mid \\
\hline 8 & 2 & $\begin{array}{l}\text { Have you ever been convicted of a publication case (before } \\
\text { the Electronic Crimes Act)? }\end{array}$ & 1.22 & .568 & $41 \%$ & mid \\
\hline \multicolumn{3}{|c|}{ The total mean of the contribution. } & 1.94 & .401 & $65 \%$ & mid \\
\hline
\end{tabular}

Table (7) shows that the extent of the contribution of the Electronic Crimes Law to the self-censorship of the performance of journalists came in relation to the contribution of the Crimes Law to self-censorship by an average of (1.94) percentage (65\%) and medium contribution, Questions about the extent of the impact of the Electronic Crimes Law on the freedom of expression of journalists between 1.22 and 2.27 and percentage ranging from $41 \%$ to $76 \%$. It came in the range of average and low contribution. The question was: Do you think that security prosecutions have (Freedom of Criticism) is ranked first by the extent to which the Electronic Crimes Law contributes to censorship (2.27) percentage (76\%) and the average contribution level, followed by the question (Do you think that the punishment in the Electronic Crimes Law limited the exercise of work (freedom of cash) with an average of 2.24 and $75 \%$ ), And the extent of the contribution of the medium, while the question came (Has been convicted of a case concerning publication (before the law of electronic crimes)?) At the last level of the contribution of the laws to self-censorship of journalists and the average (1.22) percentage (41\%) and the extent of contribution Low.

\section{Discussion of results}

1. The study showed that the extent of the general press practice in Jordan and the digital media in particular, their monitoring role before and after the issuance of the Crimes Law came to the general average of the practice with an average of 2.39 and a high level of practice. The article stated that the article, Electronic Crimes Law) ranked first in terms of practice and with a high level of practice.

2. The paragraph states that "Jordanian laws guarantee freedom of information in your personal opinion" at the last level and a low level of practice of $65 \%$. This finding is somewhat similar to Al-Rifa'ud's study, which sees restrictions on freedom of opinion and expression by the executive, In all its written, read and audio formats. The Jordanian Constitution has restricted the freedom of opinion and expression and provided for it in a flexible manner that allows for the inclusion of whatever it wants on this right, which allowed the executive authority to put the restrictions it wants.

3. The study also found in the two paragraphs (the press work is subject to the control of the editor-in-chief, the editor-in-chief or the director), and the laws restrict the digital media by imposing penal sanctions (imprisonment), which have an average of 2.56 and an average practice, Their freedom of press means that the majority of restrictions on freedom of the press in Jordanian legislation are authoritarian in nature, far beyond the requirements of the organization, and that the laws governing freedom of the press are unbalanced and tend to impose power at the expense of freedom.

4. The study showed that there is a clear imbalance in the Electronic Crimes Law, which is in no way compatible with the journalist's right to criticism. The arithmetic average of all the paragraphs related to sources of imbalance between 3.36 and 3.95 ranged from high to medium. It includes natural and legal persons at the 
first and highest levels, followed by the paragraphs "Electronic Crimes Law does not discriminate between journalists and non-journalists within the scope of responsibility. The Electronic Crimes Law does not discriminate in terms of responsibility between publication on the website and social networking sites And this indicates that this law did not distinguish between any website and another and between the journalist protected under the Press and Publications Law and ordinary persons, that is, it extended the charge department to all those who criticize, whatever their status, and thus gave a justification for holding journalists accountable. This leaves much room for ill-treatment and abuse by the authorities. This is much like the Baloch study, which in Pakistan's Electronic Crimes Bill 2016 aims to restrict Internet freedom, including freedom of expression, leaving enough room for abuse. And give it Full control of shared information on the Internet and legitimate surveillance.

5. The study found that journalists and employees of the digital media have a fairly large knowledge of criticism and related supervisory roles and that they know what they have and what they have to do. (The right of criticism is "to express an opinion on a matter or work without prejudice to the person of the author or work, that is, not prejudicial to his honor or consideration") with an average of (4.23) and the extent And the paragraph (the right of criticism is denigrated and permissible) is at the last level (2.40) and a medium level of knowledge, but the paragraph is obtained (the journalist can freely use words, drawings or pictures commensurate with the gravity of the act, however harsh) with an average of 3.33 and the average practice and paragraph.) Publishing personal images in public places of the public Freedom of criticism) with an average of 3.07 and a medium practice, which is not compatible with the freedom of criticism, that is, workers in the digital media may fall into this error because they believe in his health, which could expose them to liability and trial under the Electronic Crimes Law.

6. The study found that the degree of Jordanian journalists' attitudes towards the electronic crime websites to the restrictions imposed by the Electronic Crimes Law came to the general mean of the trend level at an average of 1.90 and to a medium degree, while the arithmetic averages of the questions regarding the trends towards the restrictions ranged from 1.63 to 2.24 , Where the paragraph (Do you agree to include the electronic publication of the Electronic Crimes Law?) Ranked first in the degree of trends towards the restrictions imposed by the Electronic Crimes Law and with an average mean (2.24) and medium degree, followed by paragraph (Do you agree to restrictions (In the case of the electronic press?) With an average of (2.08) and a medium degree, while (did you agree with the arrest of journalists according to the text of Article 11 of the Electronic Crimes Law?). In the digital media to impose sanctions to protect the ethics of the profession, despite the desire not to leave open the way for violations by some in some websites.

7. Regarding the extent of the impact of the Electronic Crimes Law on the freedom of expression of journalists on the Internet, the average of the effect of the law on the freedom of expression of journalists was 2.23 and the effect of the average, while the arithmetical averages of the questions concerning the extent of the effect of the Electronic Crimes Law, 1.99 and 2.35), and came with a high and average effect. The question was, "Are you more cautious in using your freedom to criticize public figures?" Is the Electronic Crimes Law restricting freedom of expression on websites and social networking sites? Electronic signature on the freedom of expression of journalists with an average of (2.35) and with a high impact.

8. The study showed that the extent of the contribution of the Electronic Crimes Law to the self-censorship of the performance of journalists came to the general average of the extent of the contribution of the Crimes Law to self-censorship (1.94) Between (1.22 and 2.27) and ranged between the extent of the contribution of the average and low, where the question (Do you think that security pursuits are limiting the exercise of work (freedom of criticism)) the first rank the extent of the contribution of the law of electronic crimes in selfcensorship of the performance of journalists and average arithmetic (2.27) and the extent of the average contribution, followed by the question (Do you think that the punishment in the Code of Electronic Crimes, which limited the exercise of work (freedom of criticism) with an average of (2.24) and the extent of the contribution of medium. This is consistent with the study Khaddam and Rawashdah that one of the most important Difficulties faced by journalists are that the security services call them, the threat and temporary suspension of work, the trial, which is not consistent with the theory of social responsibility, which stresses that interference in the affairs of the press must be in the public interest, especially that the question (Do you think the authority of the director or The editorial head and joint responsibility for publishing are limited by (Freedom of criticism) came in fifth place with an average of 2.1 and a medium contribution, which is considered a pre-censorship and reflects that the pressures on media practices include not only the media but also his subordinates as they become gatekeepers for the government and the interests of their institutions without clear criteria for a profession the press.

After reviewing the results, the study recommends the following:

1. Article 11 of the Cybercrime Law should be amended so that it does not include press work and does not permit the imprisonment or imprisonment of journalists. The Cybercrime Act is not the best way to regulate 
publishing on websites.

2. Abolish all restrictions imposed on the Internet, stop censorship and censorship policies, encourage Internet media and blogging, and form free electronic media communities.

\section{References}

Ali, Ismail Mahmood (2015), Digital Media and theoretical and Applied Challenges, (I 1), Alexandria: Al-Wafa Legal Library.

Al-Khaddam, Hamza and Al-Rawashdeh, Maysa (2013), Media Practice between Professionalism, Law and Tradition in Jordan, Jordanian Journal of Social Sciences, Vol. (6): 430-448.

Amman Appeal Court Decision No. 13805/2009

Ar-Rofoo' , Amal (2010), Judicial Control of Decisions Restricting Freedom of Opinion and Expression, Comparative Study between Jordan and Egypt, Amman: Amman Arab University.

Baloch, Haroon (2016), Internet Rights and Legislation in Pakistan: A Critique on Cyber Crime Bill, available on http://www.netfreedom.pk/wp-content/uploads/2016/06/CSO-criticism-on-PECB-2016_IssuePaper.pdf

Fish, Eric (2009), Is Internet Censorship compatible with Democracy? Legal Restrictions of Online Speech in South Korea, Netherlands, Asia-Pacific Journal on Human Rights and the Law 2: 43-96.

Freedom of the Press 2017 Report (2017), Freedom house, available online https://freedomhouse.org/report/freedom-press/freedom-press-2017.

Hwang, Katherine and Laing, Naysha and Holder, Christina (2016), The Right to Freedom of Expression on the Internet as it applies to Social Media in Africa,The Association of the Bar of the New York City.

Joseph, Sarah (2012), Social Media: Political Change, and Human rights, Boston College International \& Comparative Law Review, Vol. 35:145.

Momani, Muhammad (2014), Fall Media: A Speech of Incitement, Violence and Dependence, Forum of Defenders of Media Freedom in the Third Arab World, Amman, 10-11 May.

Nasr, Hossni (2014), Patterns of Control of Electronic Journalism in the Arab World in the Light of the Paper Journalism Experience: An Evaluation Study, published study, Cairo University.

Praeli, Yvette Sierra (2010), New Media and Freedom of the Press, University of Oxford.

Qutishat, Muhammad and Hossni, Walid (2015), under the microscope: Diagnosis of the Media Situation in Jordan, Amman: Center for the Protection and Freedom of Journalists.

Ramadan, Omar Said (1986), Penal Code, Cairo: House of Arab Renaissance.

Sahl , Dahir (2014), Civil Liability of Electronic Media for Violations of Personal Rights, Irbid: Yarmouk University.

Shteiwi, Moussa (2012), Electronic Media between Freedom and Responsibility, published article, tomorrow, August 30, available at https://goo.gl/RjfSwx

Sorour, Tariq (1997), Lessons in Publishing Crimes, (I 1), Cairo: The Arab Renaissance House. 